MASTER

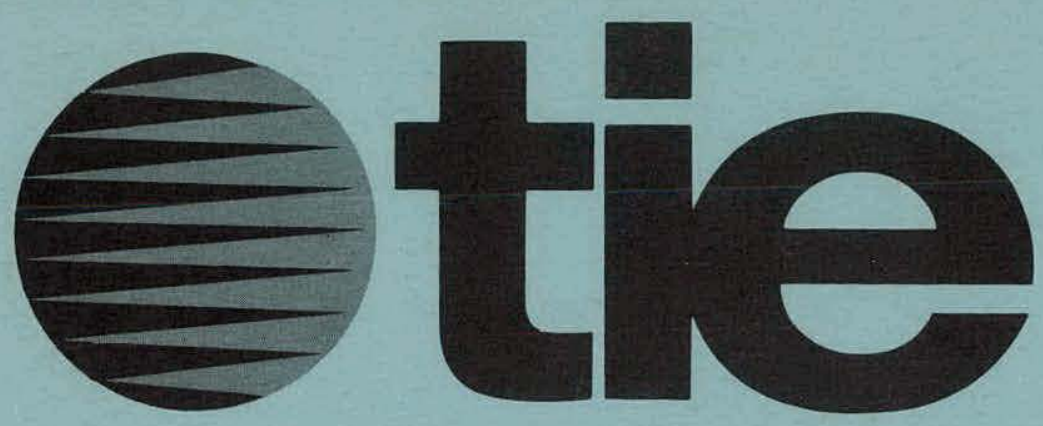

\title{
THE ROLE OF ORGANIC SOILS IN THE WORLD CARBON CYCLE - PROBLEM ANALYSIS AND RESEARCH NEEDS
}

Report of a Workshop

Indianapolis, Indiana

May 7-8, 1979

Prepared for:

DEPARTMENT OF ENERGY

Office of Environment

Office of Health and

Environmental Research

Carbon Dioxide and Climate

Research Program

DOE Report No. DOE/EV/10040-2 


\section{DISCLAIMER}

This report was prepared as an account of work sponsored by an agency of the United States Government. Neither the United States Government nor any agency Thereof, nor any of their employees, makes any warranty, express or implied, or assumes any legal liability or responsibility for the accuracy, completeness, or usefulness of any information, apparatus, product, or process disclosed, or represents that its use would not infringe privately owned rights. Reference herein to any specific commercial product, process, or service by trade name, trademark, manufacturer, or otherwise does not necessarily constitute or imply its endorsement, recommendation, or favoring by the United States Government or any agency thereof. The views and opinions of authors expressed herein do not necessarily state or reflect those of the United States Government or any agency thereof. 


\section{DISCLAIMER}

Portions of this document may be illegible in electronic image products. Images are produced from the best available original document. 


\title{
THE ROLE OF ORGANIC SOILS IN THE WORLD CARBON CYCLE -
}

\section{PROBLEM DEFINITION AND RESEARCH NEEDS}

\author{
Edited by \\ T. V. ARMENTANO
}

\section{Work Supported by \\ U.S. DEPARTMENT OF ENERGY \\ OFFICE OF ENVIRONMENT}

Contract No. 79EV10040.000

The Institute of Ecology (TIE)

Indianapolis, Indiana 46208 1979

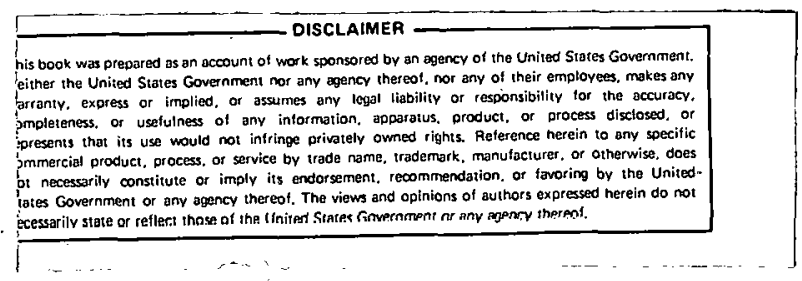




\section{PREFACE}

The continuing rise in the carbon dioxide content of the atmosphere has produced concern that climatic, ecological, and societal effects that will not easily be reversed may occur in the next half-century throughout the world. This prospect has encouraged a critical assessment by the U.S. Department of Energy of the many elements in the global carbon cycle, including man's influence on it.

Because of uncertainty about the dynamics of ecosystem response to human intervention and lack of data on carbon content in many ecosystems, there is disagreement about how much the terrestrial biosphere contributes to carbon accumulation in the atmosphere. However, the role of the terrestrial biosphere in the world carbon budget has been underscored by recent evidence that reduction of the world's biota may be adding at least as much carbon to the atmosphere as is added by combustion of fossil fuels.

The Office of Carbon Dioxide Effects Research and Assessment of the U.S. Department of Energy has funded The Institute of Ecology (TIE) under contract. No. 79EV10040.000, to evaluate three of the terrestrial biospheric components that may be important to the world carbon cycle. They are the temperate zone forest (particularly during the past 100 years), freshwater systems subject to eutrophication, and organic soils. The Institute of Ecology has held a workshop on each component, with 10 to 12 researchers on each panel. Each workshop produced data analysis, problem definition, and recommendations for further research.

This report is a summary of the findings and recommendations of the workshop on organic soils, which met in May 1979, at The Institute of Ecology.

Thomas V. Armentano

August, 1979 


\section{TABLE OF CONTENTS}

Page

EXECUTIVE SUMMARY. . . . . . . . . . . . . . . . . . . . i

INTRODUCTION . . . . . . . . . . . . . . . . . . . 1

SOILS AS SOURCES OF ATMOSPHERIC $\mathrm{CO}_{2} \cdot$. . . . . . . . . . . . . . . 1

PRESENT CARBON POOL SIZES IN THE WORLD'S SOILS . . . . . . . . . 5

ORGANIC SOILS. ........................ 8

Total Areas of Organic Soil Deposits. . . . . . . . . . 9

Utilization of Gleysols ................. . . 9

Utilization of Histosols. . . . . . . . . . . . . 12

PRIMARY PRODUCTION AND GROWTH OF WETLANDS ECOSYSTEMS . . . . . . . . 17

MANAGEMENT OF PEATLANDS. . . . . . . . . . . . . . . . . . 22

DATA UNCERTAINTIES AND RESEARCH NEEDS. . . . . . . . . . . . . . 25

Uncertainties in Available Data . . . . . . . . . . 25

Research Recommendations. . . . . . . . . . . . 28

WORKSHOP CONCLUSIONS . . . . .................. 31

LITERATURE CITED . . . . . . . . . . . . . . . . . . . . 33

WORKSHOP PARTICIPANTS. . . . . . . . . . . . . . . . . . 37 


\section{EXECUTIVE SUMMARY}

The poorly drained organic soils of the world tie up carbon under natural conditions, but when drained, these soils may release large quantities of carbon to the atmosphere.

In May, 1979, The Institute of Ecology held a workshop to determine the role of organic soils in the global carbon cycle and to ascertain their past, present and future significance in world carbon flux. Wetlands ecologists and soil scientists who participated in the workshop examined such topics as "Soils as Sources of Atmospheric $\mathrm{CO}_{2}$ ", "Organic Soils", "Primary Production and Growth of Wetlands Ecosystems", and "Management of Peatlands".

The major finding of the workshop is that the organic soils are important in the overall carbon budget. Histosols and Gleysols, the major organic soil deposits of the world, normally sequester organic carbon fixed by plants. They may now be releasing enough carbon to account for nearly $10 \%$ of the annual rise in atmospheric content of $\mathrm{CO}_{2}$.

Other principal findings of the workshop analys is of organic soils and the world carbon cycle include the following:

- Current annual release of carbon from organic soils is estimated to fall within the range of 0.03 to $0.37 \times 10^{9} \mathrm{t}$, a release equivalent to $1.3 \%$ to $16 \%$ of the annual increase of carbon in the atmosphere. If half of the released carbon remains airborne, organic soils contribute $0.6 \%$ to $8.0 \%$ of the annual rise in $\mathrm{CO}_{2}$. Uncertainties in data suggest the actual release could lie outside the range.

- Present annual releases of carbon from the Everglades Agricultural Area in Florida and the Sacramento-San Joaquin Valiey in California are estimated at $0.017 \times 10^{9}$ tons. When combined with additional carbon release from other known drainage programs and the possibility of major drainage activity in the tropics, this figure suggests that the lower limit of the world estimate of carbon release from organic soils is too low.

- Annual sequestering of carbon by undrained organic soils has been estimated at about $0.045 \times 10^{9}$ tons. This estimate is based on only a few studies, however, and precision is probably no better than an order of magnitude. This sequestering estimate exceeds the lower limit of the release estimate, but it is unlikely that the current net exchange by organic soils could in fact approach zero.

- Several strategies for peatland management are available, including creation, preservation, functional designation, and use of wetlands for agriculture and energy supply. 
Major organjc soil data inadequacies exist for total area, pool size, distribution, and depth of organic soils, amount of soil carbon deposits, amount of annual carbon release, extent of drainage activities, and contribution of temperate zone organic soils to the rise of atmospheric carbon in the 19th and 20th centuries.

To reduce uncertainties in data on organic soils, workshop participants recommend a number of research initiatives. These include:

- Critical areas for which further organic soils data are needed should be identified, and a well-defined field measurements program, coupled with remote sensing and vegetation analys is, should be initiated at carefully chosen sites.

- Sites that are undergoing drainage or will be subject to drainage in the near future should be located, and in areas where major interventions are likely, soil samples should be analyzed and permanent benchmarks established to monitor subsidence rates.

- Foreign and U.S. scientists should meet to compile information on peatland development programs and to plan a program of field measurements.

- Remote sensing should be explored as a means of estimating areal changes that result from the spread of agriculture or urbanization of wetlands.

- The effects of pollutants and of changing climate on wetlands should be studied.

- Implications for the world carbon cycle of the large-scale utilization of peat that may result from the current search for reliable energy resources should be examined. 


\section{INTRODUCTION}

Over the past three decades a continuous rise in atmospheric carbon dioxide concentration has been detected by modern, reliable methods (Keeling et al. 1976). The $\mathrm{CO}_{2}$ rise has been closely associated with combustion of fossil fuels, which has been increasing regularly since about 1860 (Baes et al. 1977). However, recent reviews of the problem (Bolin 1977, Woodwell $\frac{\text { et }}{\mathrm{aT}}$. 1978) have suggested-that additional carbon beyond that from fossil fue $\frac{1 \mathrm{~s}}{\mathrm{~s}}$ is released into the atmosphere by reduction of the biosphere, principally through destruction of tropical forests. Other potentially significant carbon sources are the poorly drained organic soils of the world, which tie up organic matter under natural conditions. These deposits, if drained, may release large quantities of carbon. Whether sufficient data exist to determine accurately pool sizes of organic soil deposits and their releases of carbon is problematical. The need for acquiring such data depends primarily on whether carbon fluxes between the atmosphere and organic soils are likely to be significant in the world carbon balance.

The Institute of Ecology assembled specialists in soil science and wetlands ecology to examine the significance to the world carbon budget of carbon release from organic soils. The following objectives were addressed in a workshop held in May, 1979:

1. Review and analysis of available data on carbon in organic soils from the past century to the present

2. Assessment of the probable flux of carbon to and from organic soils in the near future

3. Identification of major data inadequacies which preclude reliable analysis of the principal processes influencing carbon flux in organic soils

4. Proposal of research initiatives which could improve understanding of organic deposits in relation to the carbon cycle within a time frame of two to four years

\section{SOILS AS SOURCES OF ATMOSPHERIC $\mathrm{CO}_{2}{ }^{*}$}

Soil carbon is a major component of the world carbon cycle, exceeding by up to three times the quantity of carbon in the world biota or in the atmosphere (Bohn 1976). Estimates of the current and past transfer of carbon from soils to the atmosphere vary widely (Table 1) and seldom distinguish organic soils from soils as a whole. Estimates of the release of carbon to the atmosphere resulting from human intervention over the last century have been based principally on carbon isotope analyses, which

*Based on analysis and presentation by T. V. Armentano 
leave little basis for evaluating the importance of extensive drainage programs in biospheric carbon release. For soils as a whole, estimates of cumulative carbon release differ over two orders of magnitude (Table 1). Estimates of carbon released from soils alone, or as components of total biospheric flux (Table 1) are sufficiently large to suggest that an important fraction of the carbon added to the atmosphere over the last century originated in the biosphere, principally in soils and in forest trees. Wilson (1978), for example, concludes that clearing and ploughing of midcontinental rich grassland and organic soils of North America, Europg, New Zealand and South Africa between 1860 and 1890 released $110 \times 10^{9}$ metric tons of carbon -- enough to raise the atmospheric $\mathrm{CO}_{2}$ concentration by $10 \%$ and still. allow for $50 \%$ absorption by the oceans. This increment would have accounted for most of the $\mathrm{CO}_{2}$ rise over the 30 years when fossil fuel combustion was relatively small.

Direct measures of the loss in carbon from long-term cultivation have been made principally in better-drained soils (Table 2). Paul (1976) estimates a carbon loss ranging from 2.76 to $6.6 \mathrm{~kg} \cdot \mathrm{m}^{-2}$ for brown and black chernozems over the past 60 to 75 years. These losses may be representative of the $2.83 \times 10^{7}$ ha of prairie under cultivation in western Canada. In this area, if brown and black chernozems were equally distributed the total carbon released would equal $1.3 \times 10^{9} \mathrm{t}--$ about $1.5 \%$ of the $\mathrm{CO}_{2}$ increase in the atmosphere since a century ago $\left(85 \times 10^{9} \mathrm{t} \mathrm{C}\right.$, equivalent to a $40 \mathrm{ppm}$ rise in $\mathrm{CO}_{2}$ concentration). If ten times that amount were released from other cultivated soils in the temperate zone, the total would be $15 \%$ of the total rise in $\mathrm{CO}_{2}$ concentration, less than one-eighth the release suggested by Wilson (1978). Since many organic soils, like some upland soils, probably have released greater quantities of carbon than the chernozems (Table 2), the aggregate loss from soil cultivation would be somewhat higher, clearly a significant fraction of the rise in atmospheric $\mathrm{CO}_{2}$, although less than Wilson's estimate. The proportion of carbon released from organic soils alone cannot be calculated without further analysis of the historical trends in organic soil cultivation and carbon release.

Current estimates of the annual release of carbon from soils range from 0.1 to $5.0 \times 10^{9} \mathrm{t}$ (Table 1), but these figures are not strictly comparable since the larger figure includes timber harvest. . Furthermore, estimates by Bolin (1977) and Woodwell et al. (1978) emphasize the temperate zone, while Hampicke (1979) thinks losses are greatest in the tropics. In each of these cases, the basis for the estimate is a weak one, and the authors recognize that higher fluxes are quite possible. Estimates of the cumulative carbon flux from soils range over two orders of magnitude (Table 1 ). Only part of this variation comes from the differences in the time periods under consideration. Data uncertainties are clearly large, and refinement is needed.

Estimates of the cumulative flux of carbon from the biosphere range from 70 to $208 \times 10^{9}$ t $C$ over approximately a 100-year perjod, beginning in 1850 (Table 1). Most of these results derive from ${ }^{13} \mathrm{C} /{ }^{12} \mathrm{C}$ isotope analysis, the only method which gives a cumulative total flux of carbon. Estimates 
Table 1. Estimates of total release of carbon since the 19th century and the current annual rates of carbon release from soils and from the biosphere.

\begin{tabular}{lccl}
\hline & & \multicolumn{1}{c}{$10^{9} \mathrm{tc}$} \\
\cline { 2 - 4 } $\begin{array}{c}\text { Release of } \\
\text { Carbon from Soils }\end{array}$ & $\begin{array}{c}\text { Cumulative } \\
\text { Release }\end{array}$ & $\begin{array}{c}\text { Current } \\
\text { Annual } \\
\text { Rèlease }\end{array}$ & \multicolumn{1}{c}{ Comments } \\
\hline Revelle and Munk (1977) & 25 & & $1860-1970$ \\
Bolin (1977) & $10-40$ & $0.1-0.5$ & $\begin{array}{l}\text { Cumulative release since early } \\
\text { 19th century } \\
\text { Loomis (1977) }\end{array}$ \\
Wilson (1978). & $1-3$ & $1840-1950 ;$ U.S. prairies \\
Bohn (1978) & 110 & $1-2$ & $1860-1890$ \\
Woodwell et al. (1978) & & $0.5-5.0$ & Inciludes timber harvest \\
Hampicke (1979) & 0.6 & Mostly in tropics \\
Schlesinger (1979) & & 0.8 &
\end{tabular}

\begin{tabular}{|c|c|c|c|}
\hline $\begin{array}{l}\text { Release of Carbon } \\
\text { from the Biosphere }\end{array}$ & & & \\
\hline Revelle and Munk (1977) & 72 & & $\begin{array}{l}1860 \text { - 1970; Based on USDA/FAO } \\
\text { data }\end{array}$ \\
\hline Adams et al. (1977) & & $0.4-4.0$ & Based on wood consumption \\
\hline Bolin (1977) & & $0.4-1.6$ & Net transfer \\
\hline Stuiver (1978) & 120 & & 1850 - 1950; Based on ${ }^{13} \mathrm{c} /{ }^{12} \mathrm{c}$ \\
\hline Woodwell et al. (1978) & & $7.8(2-18)$ & Net transfer; Mostly in tropics \\
\hline Wagener (1979) & 208 & & $1850-1975$; Based on ${ }^{13} \mathrm{C} /{ }^{12} \mathrm{C}$ \\
\hline Freyer (1979) & 70 & $3 \pm 2$ & 1850 - 1974; Based on ${ }^{13} \mathrm{C} /{ }^{12} \mathrm{C}$ \\
\hline Chan et al. (1979) & 121 & $2.6-2.9$ & Computer model simulation \\
\hline Hampicke (1979) & & $1.5-4.5$ & Mostly in tropics \\
\hline
\end{tabular}


Table 2. A partial survey of carbon losses in soils subject' to long-term cultivation.

\begin{tabular}{|c|c|c|c|c|}
\hline Site & Soil Type & $\begin{array}{l}\text { Length of } \\
\text { Cultivation } \\
(y r)\end{array}$ & 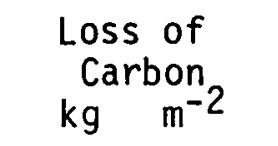 & Source \\
\hline Saskatchewan & $\begin{array}{l}\text { Chernozem } \\
\text { (brown) }\end{array}$ & $60-75$ & (top $30 \mathrm{~cm})$ * & Paul (1976) \\
\hline Saskatchewan & $\begin{array}{l}\text { Chernozem } \\
\text { (black) }\end{array}$ & $60-75$ & (top $30 \mathrm{~cm}$ ) & Paul (1976) \\
\hline Georgia piedmont & Sandy loam & 25 & (top $2.24 \mathrm{~cm}$ ) & Giddens (1957) \\
\hline Missouri prairie & Silt loam & 60 & (top $18 \mathrm{~cm}$ ) & Jenny (1941) \\
\hline $\begin{array}{l}\text { USSR } \\
\text { (European) }\end{array}$ & Gray forest & 100 & $($ top $10.2 \mathrm{~m})$ & $\begin{array}{l}\text { Rubilin \& } \\
\text { Dolotov (1967) }\end{array}$ \\
\hline $\begin{array}{l}\text { USSR } \\
\text { (trans-Gaucasus) }\end{array}$ & Podzolic & $?$ & $\left(\right.$ top $\left.i^{9.9} \mathrm{~m}\right)$ & $\begin{array}{l}\text { Tyurin in } \\
\text { Rubitin \& } \\
\text { Dolotov (1967) }\end{array}$ \\
\hline USSR & $\begin{array}{l}\text { Sod-podzolic } \\
\text { (unmanured) }\end{array}$ & 48 & $\begin{array}{c}52 \% \text { of } \\
\text { virgin humus }\end{array}$ & Kononova (1966) \\
\hline USSR & $\begin{array}{l}\text { Sod-podzolic } \\
\text { (manured) }\end{array}$ & 48 & $\begin{array}{l}52 \% \text { of } \\
\text { virgin humus }\end{array}$ & Kononova-(1966) \\
\hline $\begin{array}{l}\text { USSR } \\
\text { (s teppe) }\end{array}$ & $\begin{array}{l}\text { Chernozem } \\
\text { (fallowed) }\end{array}$ & $10-12$ & $\left.\begin{array}{rrr}4 & - & 6 \\
(\text { top } & 1 & m\end{array}\right)$ & $\begin{array}{l}\text { Lazarev in } \\
\text { Rubilin \& } \\
\text { Dolotov (1967) }\end{array}$ \\
\hline
\end{tabular}

* Depth. of soil investigated. 
of the current annual rate of carbon loss from the biosphere as a whole range from 0.4 to as high as $18 \times 10^{9}$ t $C$ (Table 1 ). Comparing estimates of the carbon release for the biosphere with that for soils suggests that soils may be contributing $25 \%$ or more of the annual biospheric carbion release (Table 1), but uncertainties are at the level of an order of magnitude. Similar uncertainty characterizes estimates of cumulative releases, which suggest that soils could have contributed up to one-half of the total release from the biosphere since the mid-19th century.

\section{PRESENT CARBON POOL SIZES IN THE WORLD'S SOILS*}

The role of organic soils in the carbon cycle depends principally on the rates of loss or gain of carbon, not on pool sizes. "Since direct measures of carbon exchange are available only from a few sites, however, they must be estimated by combining information on pool sizes, geographic distribution and the extent of human intervention. Because organic soils data are not usually summarized separately from data on soils as a whole, data on the entire soil carbon pool must be examined.

Estimates of the organic carbon pool of the world's soils (including well drained and poorly drained organic soils) have been made in at least two different ways. Some estimates have been based on soils maps such as those by the United Nations Food and Agricultural Organization (FAO) or the U.S. Soil Conservation Service (Table 3). Other estimates have been made by summarizing available data for various ecosystem types (Table 4). Uncertainties in both approaches result in a wide range in estimates. The reliability of soil mapping data varies greatly between countries, with fewest data available for the tropics, but even for the comparatively wellstudied North American continent, considerable disagreement exists (Table 3 ). Mapping data errors may be large, but they are difficult to calculate. Bohn (1976) estimated that the error of his world soil assessment was $\pm 500 \times 10^{15} \mathrm{~g}$, or $17 \%$ of the mean.

Difficulties in the ecosystem or biome-type approach arise principally from the necessity of extrapolating data from a small number of studies to a large geographic area. For example, estimates by Schlesinger (1977) of the soil carbon in the arctic and alpine tundras of the worid were based on 31 sampling stations and 11 references; in the boreal forest, 21 stations and 7 references; and in the temperate grasslands, 18 stations and 6 references. The coefficient of variation of the estimates for the boreal forest was $53 \%$, and it was even higher for swamps and marshes and for the tundra.

Schlesinger (1979) has recently revised his estimate of world soil carbon, based on new data (Table 4). The revised estimate, based on an addition of 35 stations to the compilation of Schlesinger (1977), is $1515 \times 10^{9} \mathrm{t}$ of carbon, $4 \%$ higher than the previous estimate. No information is provided on the variability of the new data. For the boreal forest,

*This section was adapted from an analys is and presentation by $T$. V. Armentano. 
Table 3. Quantities of organic carbon accumulation in the sgil, based on FAO-UNESCO data and maps. Data are in $10^{9}$ tons of carbon.

\begin{tabular}{|c|c|c|}
\hline Continents & $\begin{array}{l}\text { Bohn } \\
(1976)^{\star}\end{array}$ & Ajtay $\frac{\text { et }}{(1979)^{\frac{a l}{x}}}$ \\
\hline North America & $665^{\circ}$ & $248^{\circ}$ \\
\hline U.S.A. & & 135 \\
\hline $\begin{array}{c}\text { Central America } \\
\text { (incl. Mexico) }\end{array}$ & & 48 \\
\hline South America & 301 & 306 \\
\hline Africa 7 & & 320 \\
\hline Asia & & 541 \\
\hline Europe $\quad-$ & 1980 & 74 \\
\hline USSR & & 440 \\
\hline Oceania & & 93 \\
\hline $\begin{array}{l}\text { Greenland and } \\
\text { Antarctica }\end{array}$ & & $?$ \\
\hline Terrestrial total & 2946 & $2205^{*}$ \\
\hline
\end{tabular}

* Reported in Ajtay et al. (1979) as $2070 \times 10^{9}$ tons. 
Table 4. Two recent estimates of the carbon content of soils in ecosystems of the world. Areas are given in $10^{8}$ ha and carbon content in $10^{9}$ tons.

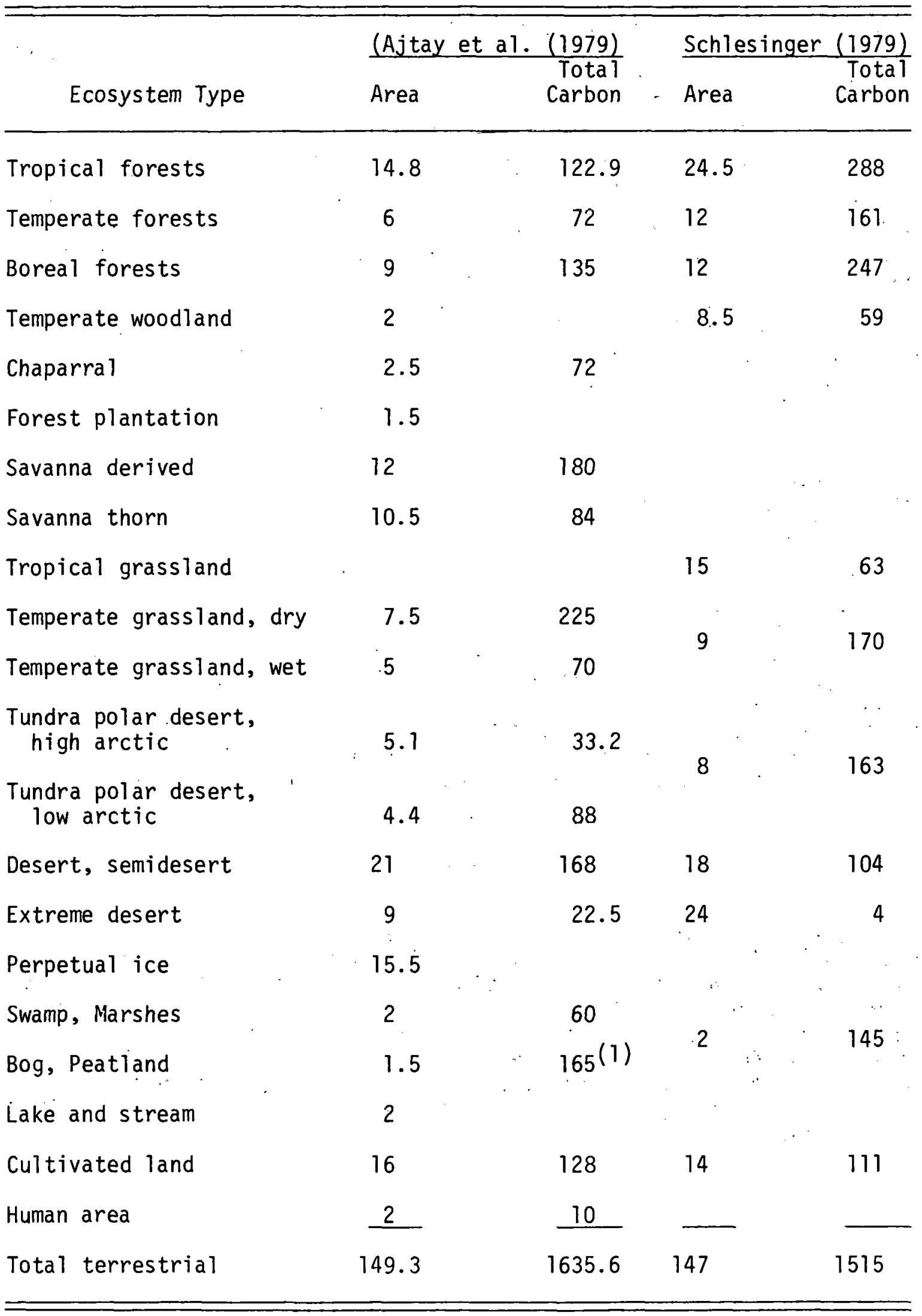

(1) Calculated from data of Moore and Bellamy (1975). 
the only ecosystem for which a breakdown of the data is given, the number of references for the new estimate is 13, and the number of sampling stations is 34 or more (one reference did not report the number of sites).

Estimates based on ecosystem types are considerably lower than those based on mapping information (Tables 3 and 4 ). The estimates of Ajtay et al. (1979) and Schlesinger (1979) are within 8\%, but differences are much greater for certain ecosystem types, partly because of disagreement on areal extent. Differences are greatest in the tropical forest estimates, where the discrepancy is over 100 percent. Schlesinger's boreal forest estimate is $83 \%$ larger than Ajtay's, while his estimate for wetlands soils is $54 \%$ smaller (Table 4 ). The estimate for boreal deposits by Schlesinger is higher, apparently because he includes peatlands within the boreal forest (Schlesinger 1979). There is agreement, nevertheless, that approximately $25 \%$ of the world soil carbon pool may be found in boreal and wetland ecosystems and another $10 \%$ in the tundra. Each of these ecosystems contains substantial deposits of wet organic soils.

A difficulty with both mapping and ecosystem-type approaches is the lack of data on depth of the deposits, which is of special significance in organic soils. Bohn's (1976) estimates are based on a depth of one meter: The literature survey upon which Schlesinger (1977) based his estimates shows wide variation in the depth of the deposits sampled, with most less than one meter. In most wetlands, deposits exceed one meter in depth, and some, such as those of the San Joaquin Valley in California, may reach a depth of six meters. Clearly, estimates of pool size in wetlands would be much larger if the entire depth of the organic deposit were included. A second uncertainty is whether the estimates by Ajtay et al. and Schlesinger include salt marsh and estuarine peat and sediment, which total about $178 \times 10^{6}$ ha in area (Woodwe11, Rich and Hall 1973). The carbon in sediments of lakes, ponds, rivers and reservoirs has apparently not been estimated.

\section{ORGANIC SOILS}

The major organic deposits of the world can be classified according to the FAO soil classification and U. S. Soil Taxonomy (Soil Survey Staff, 1974) systems as either Histosols, of which peat deposits are one type, or Gleysols. The organic soil material of Histosols, which is derived from plant residues, must contain at least 12 to $18 \%$ organic carbon by weight, and exceed $30-40 \mathrm{~cm}$ in depth. Gleysols are mineral soils with gleyed horizons. Histic Gleysols and Humic Gleysols, two of the mine subdivisions of Gleysols, may be high in organic carbon but contain less than the minimum for Histosols. 


\section{Total Areas of Organic Soil Deposits*}

Estimates of the areas of Histosols and Gleysols found throughout the world based upon the world soils map of the FAO (1971-1978) (map scale = $1: 5,000,000)$ are presented in Table 5. Bohn considers these estimates a partial update of his estimate of $431 \times 10^{6}$ ha for world Histosols (Bohn 1976).

The major distribution of Gleysols is found from latitude $20^{\circ}$ to $40^{\circ} \mathrm{N}$ in southern Asia, the U.S., China and the USSR, and around the equator in South America and Africa. Because of a paucity of data, error bounds for the estimate of Gleysol areas is not given, but is probably no better than $50 \%$ of the mean. Gleysols of Southeast Asia and other areas that have been cultivated for many decades have probably already reached their steady state organic carbon levels, but in the future it is possible that new inroads into these soils may occur, resulting in greater releases of carbon than at present.

Uncertainties in the extent of Histosols throughout the world result in estimates which differ by nearly $100 \%$ (Table 5). Major uncertainties concern the extent of Histosols in Southeast Asia, Canada, Europe, and the USSR. A widely cited estimate of peatland resources may be $40 \%$ too low (Table 6). Comparison with soils data summarized by ecosystem type (Table 4) suggests that estimates in Table 5 may be low. According to Ajtay et al. (1979), bog and peatland, swamp and marsh, and wet temperate grasslands contain large areas of Histosols and Gleysols (Table 4). The total area of these categories is $850 \times 10^{6}$ ha, which exceeds the range of 537 to $7.59 \times 10^{6}$ ha for the areal estimate of Histosois and Gleysols in Table 5 . Because of the uncertainty connected with the Gleysol estimate, the present range of mapped data estimates should be perhaps 530 to $900 \times 10^{6}$ ha. The estimates of Ajtay et al. suggest that the mapped estimate could be higher than, or near the maximum of, the suggested range. Although some wet grasslands may not have Histosols or Gleysols, other ecosystem categories, such as taiga, tundra, and certain tropical ecosystems, contain additional organic deposits.

\section{Utilization of Gleysols**}

Estimates of carbon release from Gleysols is hampered by inadequate data on pool sizes and the extent of drainage activities, present and past. Nevertheless, the approximate present annual release of carbon from Gleysols can be estimated with the following assumptions: that one percent of the world's Gleysols $\left(3 \times 10^{6} \mathrm{ha}\right)$ are being converted to agriculture by drainage, that carbon loss is $0.5 \mathrm{~kg} \cdot \mathrm{m}^{-2} \mathrm{yr}^{-1}$, and that drainage reduces organic carbon to $50 \%$ of the original carbon content. Annual release of carbon

*This section was adapted from an analys is and presentation by $H$. Bohn and D. Franzmeier.

**Based on an analys is and presentation by $H$. Bohn, D. Franzmeier and C. C. Delwiche. 
Table 5. Estimates of the major areas of Histosols and Gleysols in the world. Data based on a presentation by $\mathrm{H}$. Bohn o.f the University of Arizona. Histosols are defined as containing over 15\% organic carbon by weight." Gleysols are defined as organic soils containing less than $15 \%$ organic carbon on a wet-weight basis:

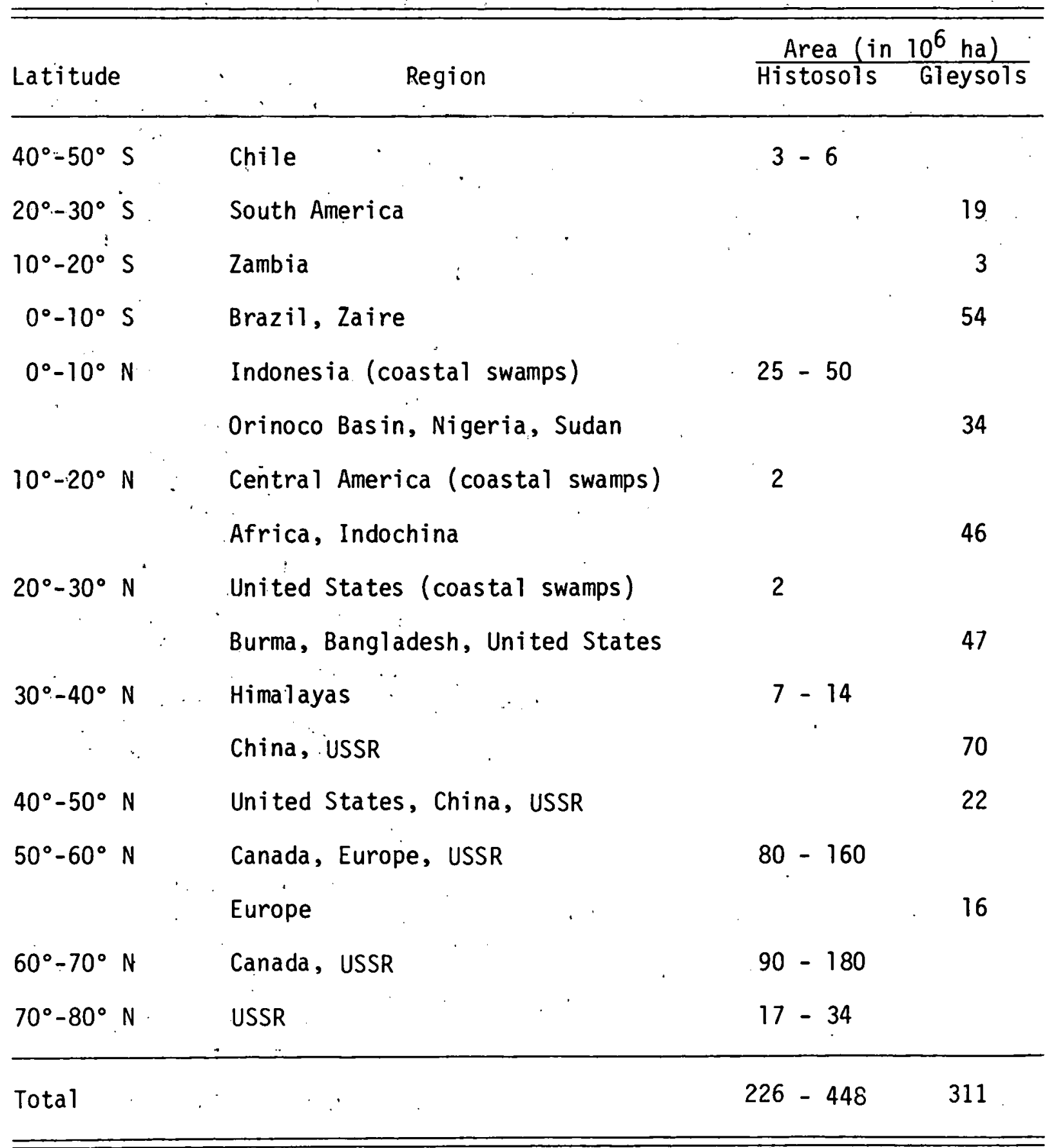


Table 6. Two estimates of the world's peat resources (in $10^{6}$ ha).

\begin{tabular}{|c|c|c|}
\hline Country & $\begin{array}{c}\text { Moore \& } \\
\text { Bellamy (1975) }\end{array}$ & Farnham ${ }^{2}$ \\
\hline USSR & 71.5 & 150.0 \\
\hline Canada & 129.5 & $112.0^{\circ}$ \\
\hline United States & 7.5 & 21.0 \\
\hline Finland & 10.0 & 9.7 \\
\hline Sweden & 1.5 & 7.8 \\
\hline East/West Germany & 1.6 & 5.2 \\
\hline Great Britain/Ireland & 1.8 & 5.2 \\
\hline Poland & 1.5 & 3.4 \\
\hline Norway & 3.0 & 3.0 \\
\hline Indones $i a / M a$ laysia & $0.7^{1}$ & 2.4 \\
\hline A11 others & 1.9 & 2.2 \\
\hline Total & 230.5 & 321.9 \\
\hline
\end{tabular}


would then equal a world total of $0.015 \times 10^{9} \mathrm{t} \mathrm{yr}^{-1}$. This estimate of carbon loss may be somewhat high, because the $1 \%$ annual drainage rate could exist only over the short term during the period of rapid drainage.

Delwiche independently estimated an annual loss of carbon of $0.01 \times 10^{9} t$ $\mathrm{yr}^{-1}$, by assuming that $10^{6}$ ha of Gleysols are exposed to drainage per decade and that oxidation releases $10 \mathrm{~kg} \mathrm{~m}^{-2} \mathrm{C}$. In the United States and Europe, where there is adequate capital and advanced technology, this rate of change could occur. In Africa and in Southeast Asia, where land utilization is more stable and follows population pressure, rather than economic fluctuations, utilization of Gleysols is probably nearly complete. In Southeast Asia, Gleysols are attractive for rice, because the fine soil texture simplifies water control. Recently increasing interest in dry-land rice growing may reflect the lack of availability of new gleysol soils.

\section{Utilization of Histosols*}

World Trends

No more than $15 \%$ to $25 \%$ (i.e., about 50 to $70 \times 10^{6} \mathrm{ha}$ ) of the world's Histosols are found in climates that are suitable for agriculture: On an average, approximately $10 \%$ of these lands, or 5 to $7 \times 10^{6}$ ha, are now.being farmed. As a maximum, no more than $50 \%$, or 25 to $35 \times 10^{6}$ ha, could be developed for agriculture. The release of carbon from Histosols that are now being cultivated or could feasibly be cultivated in the future would then vary from about 0.05 to $0.35 \times 10^{9} \mathrm{yr}^{-1}$ (assuming an annual. release of $10 \mathrm{tha} \mathrm{h}^{-1} \mathrm{yr}^{-1}$ ), but may be only one-half or one-fourth of this estimate. These carbon output rates would be relatively constant until the Histosols were consumed by oxidation.

A second estimate of carbon release from Histosols assumes that annual rate of oxidation of organic matter destroys 1 to $3 \mathrm{~cm}$ of soil, that bulk density of Histosols is $0.15 \mathrm{gm} \mathrm{cm}-3$, and that one-half of the organic matter is composed of organic carbon. Under these conditions the evolution of carbon would range from 0.02 to $0.07 \times 10^{9} \mathrm{t} \mathrm{yr}^{-1}$. Peatlands that are not adequately drained for crop production may be subsiding at rates one order of magnitude less than the 1 to $3 \mathrm{~cm}$ estimate given. The area of incompletely drained peatlands, and the reliability of the estimate of subsidence rates and carbon release, are not known. Delwiche (this workshep) calculated that $0.1 \times 10^{9} \mathrm{t} C$ may be released annually from. $2 \times 10^{6}$ ha of Histosols subsiding at an annual rate of $5 \mathrm{~cm}$. He estimated the precision of the area determination to be about $20 \%$ of the mean; of the oxidation rate, $30 \%$, and of the extent of exposure of Histosols, $50 \%$. Undertainty about Gleysols is of the same order.

Under nearly ideal laboratory conditions, decomposition rates for a Canadian histosol varied from less than $50 \mathrm{ppm}$ to $1200 \mathrm{ppm}$ of carbon per day. At a rate of $200 \mathrm{ppm}$ of carbon per day, decomposition in the top

*Based on analyses and presentations by J. Duxbury, R. Farnham, H. Bohn and D. Franzmeier. 


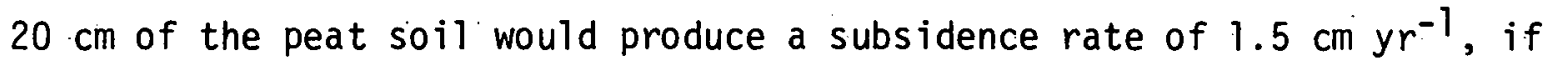
all the loss in volume results from carbon loss. For soils with bulk densities ranging from 0.1 to $0.4 \mathrm{~g} \mathrm{~cm}^{-3}$, the amount of carbon evolved annually would vary from 5.8 to $23.4 \mathrm{t} \mathrm{ha-1.} \mathrm{At} \mathrm{this} \mathrm{rate,} \mathrm{drainage} \mathrm{of} 2 \times 10^{6}$ ha of organic soils would release 0.01 to $0.05 \times 10^{9} \mathrm{t} \mathrm{C}$, within the range of estimates previously presented in this report. Although laboratory rates are usually higher than field rates, these laboratory estimates are relatively low because they are based on soils with a frost-free period of 120 days.

Less is known about the massive peat deposits in North and South America (Guayana, Surinam), eastern Indonesia (Borneo and Sumatra), and Southeast Asia than for other areas. Neither the total extent of these deposits nor their depth over large areas is known, so the total size of the pools cannot be estimated. Although efforts are underway to drain these deposits, the extent of these efforts and their success are unknown. However, the potential for large releases of carbon from these deposits in the near future cannot be discounted.

For lands above latitude $50^{\circ} \mathrm{N}$, probably no more than $0.1 \%$ of the Histosols (principally in Canada, USSR, and Alaska) are drained. Most of the drainage is for fuel harvesting, which does not reclaim the soils sufficiently for row crop production. Thus, carbon losses would be expected to be lower than in soils supporting row crops. In the continental United States, Europe and Scandinavia, about 5\% of the histosol areas are adequately drained for row crop production. In the tropics, little of the histosol areas are used by man, but $5 \%$ could be used for rice growing and grazing.

The total drained land north of latitude $50^{\circ} \mathrm{N}$ is estimated to be $4 \times 10^{5}$ ha, and the total drained 7 and south of latitude $50^{\circ} \mathrm{N}$ is estimated to be $2.5 \times 10^{6}$ ha, for a total of about $3 \times 10^{6}$ ha. Because of the difficulty in reclaiming Histosols, most of those with potential for development have already been drained and are being utilized. Major problems in reclaiming these soils are as follows:

1. high cost of drainage and maintenance

2. high probability of flooding

3. low nutrient content of the soils

4. above latitude $40^{\circ} \mathrm{N}$, unfavorable climate for crops

5. high, specific heat capacity of soils when wet, and very low heat conductivity when dry

6. high sulfide content in many coastal organic soils

7. generally high initial subsidence, accentuating drainage problems

8. high cost of management of local water regimes

\section{Subsidence and Carbon Release to the Atmosphere*}

Subsidence or shrinkage of organic soils usually accompanies drainage. It may be caused by any of several factors; including compaction, wind

*Based on a presentation and analysis by S. P. Mathur, L. H. Allen and J. Duxbury. 
erosion, fire, and desiccation, but the only process significant in the carbon cycle is biochemical oxidation. Because subsidence is easily measured and of practical importance for agriculture, long-term data sets are available that can provide insight into carbon release over many decades. Subsidence data alone, however, cannot be used to estimate carbon release. The rate of subsidence depends mainly on temperature, water content, and the physical nature of soil material., and depth to the water table. Subsidence rates have been found to vary from less than 1 to more than $8 \mathrm{~cm}$ per year (Table 7).

Subsidence of peat soils can also be caused by changes in bulk density, which must be considered in calculating losses of carbon. For example, the bulk density of sphagnum peat changes from about 0.05 to $0.2 \mathrm{~g} \mathrm{~cm}^{3}$ as it is humified. The initial loss in volume is from shrinkage caused by drying; as sedge peat humifies, its bulk density changes from 0.1 to $0.4 \mathrm{~g} \mathrm{~cm}^{3}$ without a substantial change in percent carbon content. Generally, the major changes in bulk density occur in the top 20 or $30 \mathrm{~cm}$ of peat, an. interval in which variation may be high and affect calculations of carbon loss (Figure 1).

The oxidation component of subsidence varies widely with climate; it is generally a smaller component of peat subsidence in cool climates than in temperate and tropical climates. Stephens (1974) reports that Russian studies show that only $13 \%$ to $14 \%$ of the total subsidence of organic soils near Minsk was caused by oxidation. The major factors were compaction and desiccation. By comparison, in the Netherlands, oxidation accounted for $20 \%$ of subsidence, and in the Everglades up to $78 \%$ of total subsidence results from oxidation.

The Everglades Agricultural Area and the San Joaquin Delta

The Everglades Agricultural Area in Florida and the Sacramento-San Joaquin Delta in California are prime farming areas developed on Histosols. These sites, subject to extensive and continuing drainage for more than 50 years, represent the best available sources of information on long-term response of peat surface elevation to water table withdrawal.

In the Everglades Agricultural Area south of Lake Okeechobee (3.1 x $10^{5}$ ha), drainage of freshwater peat was begun in 1912. Subsidence reached $1.8 \mathrm{~m}$ by 1950 (Stephens and Johnson 1951), and about $3.3 \mathrm{~m}$ by 1970 (Stephens 1974). By the year 2000. 1arge areas are expected to be reduced to 0.3 to $0.6 \mathrm{~m}$ of organic soil over a limestone base, a depth of soil too shallow for crops such as sugarcane and vegetables. Subsidence rates generally decreased exponentialiy over the first few years and then leveled off to a lower rate that typically varied from 1 to $3 \mathrm{~cm}$ per year. Major changes in bulk density have also occurred, and it can be assumed that major losses of carbon also occur during periods of major subsidence. The bulk density of the Everglades soils is about 0.23 , the soil organic matter content is about $88 \%$, and the carbon content of the organic matter averages $56 \%$. At a subsidence rate of $2.54 \mathrm{~cm} \mathrm{yr}^{-1}$, Everglades peat would release $0.009 \times 10^{9}$ $t C \mathrm{yr}^{-1}$, about $0.18 \%$ of world fossil fuel emissions. 
Table 7. Measured rates of subsidence of organic soils for specific sites in different areas. Data from survey by L. H. Allen and J. Duxbury.

\begin{tabular}{|c|c|c|c|c|}
\hline Location of Site & $\begin{array}{l}\text { Annual Subsidence } \\
\text { Rate }\left(\mathrm{cm} \mathrm{yr}^{-1}\right)\end{array}$ & $\begin{array}{l}\text { Cumulative } \\
\text { Subsidence } \\
\quad(\mathrm{cm})\end{array}$ & $\begin{array}{l}\text { Time } \\
\text { Period } \\
\text { (yr) }\end{array}$ & $\begin{array}{c}\text { Average Depth } \\
\text { to Watertable } \\
(\mathrm{cm})\end{array}$ \\
\hline $\begin{array}{l}\text { California Delta } \\
\quad(2 \text { sites })\end{array}$ & $2.5-8.2$ & $152-244$ & 25 & . \\
\hline Louisiana (estimated) & $1.0-5.0$ & & & \\
\hline Michigan & $1.2-2.5$ & $7.6-15$ & 5 & \\
\hline New York & 2.5 & 150 & 60 & 90 \\
\hline Indiana & $1.2-2.5$ & $7.6-15$ & 6 & \\
\hline $\begin{array}{l}\text { Florida Everglades } \\
\quad(2 \text { sites })\end{array}$ & $2.7^{2.7}-4.2$ & $19^{147}-29$ & $\begin{array}{r}54 \\
7\end{array}$ & $\begin{array}{l}90 \\
60\end{array}$ \\
\hline $\begin{array}{l}\text { Nether } 1 \text { ands } \\
(2 \text { sites })\end{array}$ & $1.0-1.7$ & $\begin{array}{l}70 \\
6-10\end{array}$ & $\begin{array}{r}100 \\
6\end{array}$ & 10.20 \\
\hline Ireland & 1.8 & & & 90 \\
\hline Norway & 2.5 & 152 & 65 & \\
\hline England & $0.5-5.0$ & $\begin{array}{l}325 \text { (by } 193 \\
348 \text { (by } 195\end{array}$ & $\begin{array}{l}\text { 32) } 84 \\
\text { 51) } 103\end{array}$ & \\
\hline Israel & 10 & & & \\
\hline USSR (Minsk bog) & 2.1 & 100 & 47 & \\
\hline
\end{tabular}




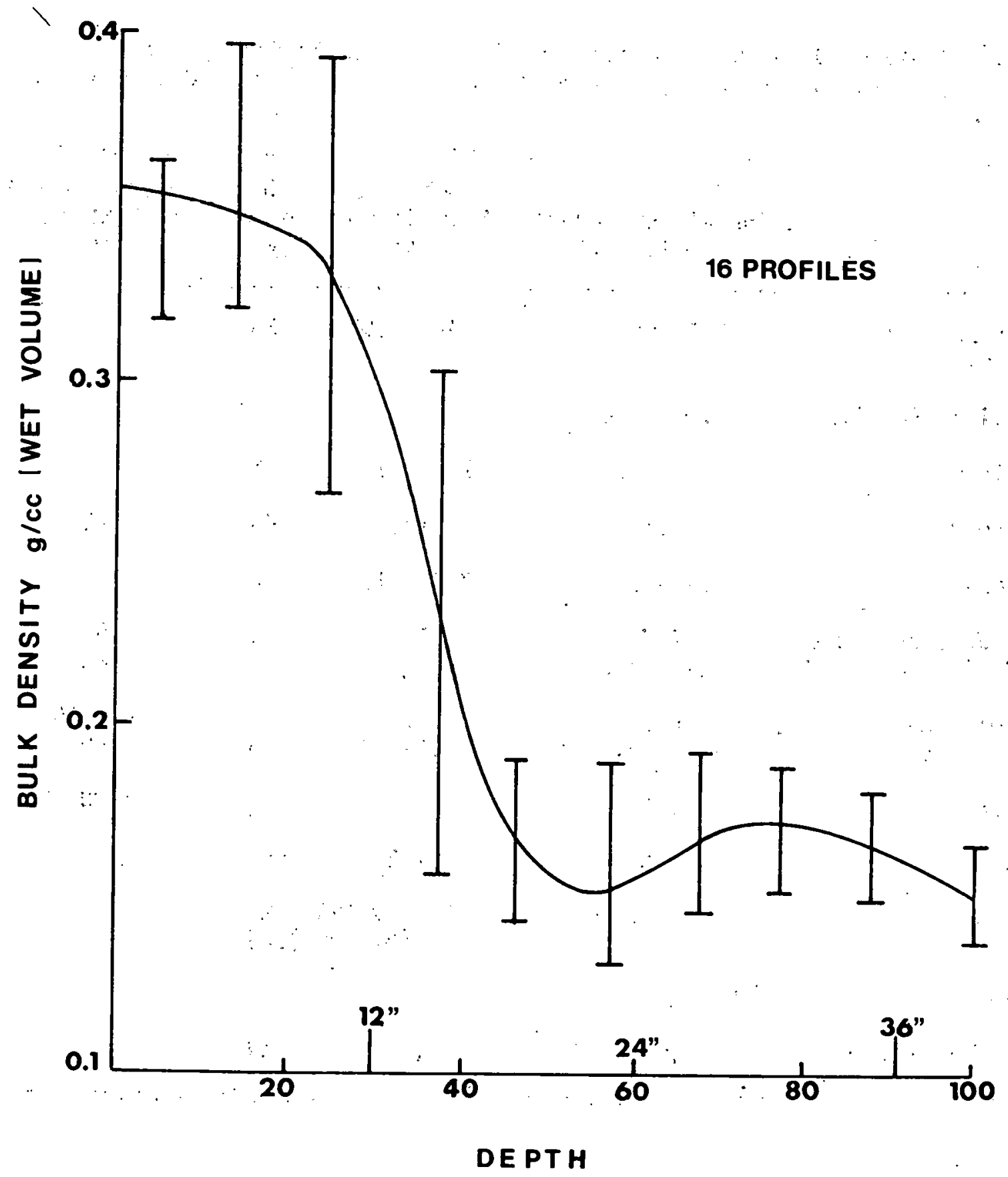

Figure 1. Depth profile of bulk density for Everglades peat. A similar profile can be found in many northern peat areas such as in New York. Data from J. Duxbury. 
The amount of carbon lost from the entire Florida Everglades, which contain over $8 \times 10^{5}$ ha, the largest area of organic soils in the world (Shih, et al. 1979) is not known. Water table withdrawal and fires may have converted the Everglades from a carbon sink into a net source of carbon dioxide. Although sediments are not as deep here as in the agricultural zone, the areal extent is much greater, and the total pool of carbon in the sediments may be larger in the sawgrass area.

In the San Joaquin Valley in California, which in 1922 was about $0.6 \mathrm{~m}$ below sea level, the peat surface had sunk by 1950 to more than $3 \mathrm{~m}$ below sea level, an average of $7.6 \mathrm{~cm}$ of subsidence per year (Weir 1950). The current level of peat surface is about $6 \mathrm{~m}$ below sea level. About $0.008 \times 10^{9}$ t $C$ is released annually from the Sacramento-San Joaquin Delta, according to Allen, who assumed a subsidence rate of $7.6 \mathrm{~cm}$ yr and an area of $10^{5}$ hectares.' The total carbon release from the Everglades Agricultural Area and tine San Joaquin Delta is $0.017 \times 10^{9} \mathrm{t}$ annually - an estimate that is $5 \%$ to $85 \%$ of the carbon release $\left(0.02\right.$ to $0.35 \times 10^{9} \mathrm{t}$ ) given for the world's Histosols previously in this report. There is considerable uncertainty as to the reliability of both global and site-specific estimates, but the latter are based on better data. Since carbon is being released from Histosols other than those in Florida and California, release from world Histosols is probably much above the lower limit of the estimate just given. A more intensive synthes is of existing data might refine present estimates, but new data are needed for areas of major deposits, particularly in the tropics. Because oxidation rates and other chemical processes are directly proportional to temperature, losses of carbon from wetland soils in subtropical and tropical regions of the world may be quite high, but data are lacking for most of these sites except the Everglades.

\section{PRIMARY PRODUCTION AND GROWTH OF WETLANDS ECOSYSTEMS*}

In the absence of intervention by man, wetlands function as natural sinks for carbon synthesized by primary production of green plants." Shortterm studies of primary production of wetlands. indicate that wetlands are highly productive (Table 8 ), with about $10 \%$ of net primary production converted to peat stored in the sediments underlying the vegetation (Reader and Stewart 1972). In the absence of fire, as much as 30\% of production " may be converted to peat in northern peatlands (calculated from Richardson 1978). Long-term vertical accretion can be estimated from carbon 14 profiles, which provide a mean over a period of time ranging from thousands to tens of thousands of years (Table 9).

Such a long-term mean must be interpreted as a net accretion, with some losses having occurred during the interval. Estimates range from up to $20 \mathrm{~cm}$ vertical accretion over 100 years in the Everglades to $2 \mathrm{~cm}$ in

\footnotetext{
*Based on an analysis by C. J. Richardson, L. H. Allen and R. Farnham.
} 
Table 8. A comparison of available data on net productivity of wetlands and some productive upland ecosystems. Data are from a literature summarization by C. J. Richardson (1979).

$\begin{aligned} \text { Ecosystem Type } & \begin{array}{c}\text { Net Productiyity } \\ \left(\mathrm{t} \mathrm{ha-1} \mathrm{yr}^{-1}\right)\end{array} \\ & \text { Number of Sites Studied }\end{aligned}$

\section{Total of Above} and Below Ground

$\begin{array}{lc}\text { Cattail Marsh } & 27.4 \pm 6.7 \\ \text { Reed Type Marsh } & 1 \\ \text { Papyrus Marsh } & 21.0 \pm 5.8 \\ \text { Fresh Water Tidal } & 90-160 \\ \text { Carex Marsh } & 10.4 \pm 1.0 \\ \text { Bogs, Fens and Muskeg } & 9.3 \pm 4.6 \\ \text { Grasslands in U. S. } & 5.1 \pm 1.5 \\ \text { Bog Forest } & 6.7\end{array}$

Above Ground Only

Swamp Forests

$10.5 \pm 3.3$

Boreal Conifer Forests

$$
9.0 \pm 3.5
$$

Pine Forests

$10.4 \pm 5.7$

Temperate Coniferous

$14.9 \pm 9.0$

Tropical Rạinforest

$16.5-28.2$

Deciduous Broad-leaf

$10.2 \pm 2.3$

1. C. Papyrus not included. 
Table 9. Retrospective dating of peat deposits in Washington (Puget Sound area) and Florida (Everglades). Dates of deposits were determined by ${ }^{14} \mathrm{C}$ techniques, and in the case of Washington by comparison with ash from the eruption of Glacier Peak about 6700 years before the present. Data from Rigg and Gould: (1957) and MacDowell, Stephens and Stewart (1969).

\begin{tabular}{|c|c|c|c|c|c|c|}
\hline \multirow[b]{3}{*}{ Area } & \multicolumn{3}{|c|}{ Thickness of Peat $(\mathrm{m})$} & \multicolumn{3}{|c|}{ Rate of Sedimentation $\left(\mathrm{cm} 10^{2} \mathrm{yr}\right)$} \\
\hline & & Dating & nterval & & Dating & Interval \\
\hline & $\frac{\text { Total Colume }}{,}$ & $11900-6700 \mathrm{BP}$ & 6700 BP-Present & Total Column & $11900-6700 \mathrm{BP}$ & $6700 \mathrm{BP}$-Present \\
\hline \multirow{2}{*}{$\begin{array}{l}\text { Puget Sound } \\
\text { (151 bogs) }\end{array}$} & 7.3 & 3.0 & 4.3 & 6.2 & 5.9 & 6.4 \\
\hline & & $3500-1200 \mathrm{BP}$ & $1200-65 \mathrm{BP}$ & & $3500-1200 \mathrm{BP}$ & $1200-65 \mathrm{BP}$ \\
\hline Everglades & 3.65 & 1.37 & 2.28 & 8.4 & 7.3 & 20.0 \\
\hline
\end{tabular}


far northern peatlands (Table 10), although other reports suggest that $10 \mathrm{~cm}$ per century is average (Bohn 197.8). For the most part, differences in reported net productivity rates (Table 8) are smaller than are differences in reported rates of carbon accumulation (Table 10), when compared over a wide range of sites. One explanation of these differences is that other processes than net productivity may be overriding factors in determining peat accumulation rates. Such characteristics as hydrology, topography, substrate chemistry, and stage in vegetation succession can be important determinants of wetland functioning in general (see Good et al. 1978, Aandahl et al. 1974), and may directly influence carbon accumutation rates. During the time interval approximated by carbon 14 dating, sea level rise may have influenced the rate of carbon deposition along coastal areas, but since it still removes carbon from the atmosphere, the process can be interpreted as a carbon sink.

Lateral growth of peatlands, or paludification, may be an important process in northern peatlands. Western Siberia has about $7.9 \times 10^{6}$ ha of peatlands that were formed 10,000 to 12,000 years ago (Neishtadt 1977). About $50 \%$ of the West Siberian Plain is occupied by mires. There has been net growth of these bogs and mires over the last 8,000 years, during the Holocene period, with an annual increase in bog area of $10^{4}$ hectares during this period. Neishtadt considers this rate of paludification to be much greater than in any other area of the world, but comparable spreading of peatlands may also be occurring in northern Canada and Alaska. In contrast, more tundra peat may be exposed to oxidation because of isostatic rebound and the melting of permafrost. Data are not available to make even a general assessment of the rate of peat expansion or peat oxidation in the northern circumboreal areas, but paludification could be functioning as a large carbon sink, offsetting carbon release from drainage of organic soils or clearing of upland soils.

Thus far, there has been little drainage of the peatlands of western Siberia, although there has been some support in Russia for their economic development. Drainage of $10^{3}$ to $10^{4}$ ha or more of wet areas in northwestern and central regions of the European part of the USSR has occurred, but the total release of carbon cannot be estimated, since the depth of the deposits and the subsidence and oxidation rates are not available. Most of the loss of carbon from these developed areas in European USSR has probably already occurred, and the major changes in the Russian peatlands are occurring in Siberia where, in the absence of major drainage schemes, paludification is probably causing a net, carbon sink.

Richardson and Allen compiled some of the data available for natural peatland accumulation rates to provide the basis for an initial approximation of carbon storage rates for the world's peatlands (Table 10). Carbon accumulation was weighted for lpwer rates in northern peatlands by assuming a world average of $100 \mathrm{~kg} \mathrm{ha}^{-1} \mathrm{yr}^{-1}$. For a peatland area of $4.5 \times 10^{8} \mathrm{ha}$, about $0.045 \times 10^{9} \mathrm{t} C$ would be added to peatlands annually. The uncertainties in total area of organic soils (Table 5) mean that the accumulation 
Table 10. Estimates of carbon accumulation rates for some natural peatlands. Calculations by C. J. Richardson and L. H. Allen.

\begin{tabular}{|c|c|c|c|c|c|}
\hline Peatland System & $\begin{array}{l}\text { Bulk } \\
\text { Density } \\
9 \mathrm{~cm}^{-3}\end{array}$ & $\begin{array}{l}\text { Accretion } \\
\text { Rate } \\
\text { cm } \mathrm{yr}^{-1}\end{array}$ & $\begin{array}{l}\text { \% Carbon } \\
\text { Content } \\
\text { of Biomass }\end{array}$ & $\begin{array}{l}\text { Carbol } \\
\text { Accumula } \\
\text { Rate in } \\
\mathrm{kg} \mathrm{ha}-1\end{array}$ & $\begin{array}{l}\text { n } \\
\text { tion } \\
\text { Peat } \\
y r^{-1}\end{array}$ \\
\hline $\begin{array}{l}\text { Florida Everglades: } \\
3500-1200 \mathrm{BP} \\
1200-65 \mathrm{BP}\end{array}$ & $\begin{array}{l}0.15 \\
0.15\end{array}$ & $\begin{array}{l}0.07 \\
0.20\end{array}$ & $\begin{array}{l}50 \\
50\end{array}$ & $\begin{array}{r}525 \\
1500\end{array}$ & \\
\hline Minnesota Peatlands & 0.05 & 0.15 & 50 & 333 & \\
\hline Northwest Territories & 0.05 & 0.02 & 50 & 50 & \\
\hline Washington State & 0.15 & 0.065 & 50 & 500 & \\
\hline $\begin{array}{l}\text { Manitoba } \\
\quad \text { (combined average) }\end{array}$ & & & 40 & 372 & \\
\hline Michigan & 0.13 & . & 40 & 110 & \\
\hline $\begin{array}{l}\text { Cattail Marsh - average } \\
\text { for } 41^{0}-45^{\circ} \mathrm{N} \text {. Latitude }\end{array}$ & 0.15 & & 40 & 996 & . \\
\hline
\end{tabular}


estimate may be too high if accumulation only in Histosols is considered. Another source of error, probably of smaller magnitude, is the loss of organic carbon from swamps. Mulholland and Kuenzler (1979) have shown the amount of organic carbon in streams draining swamps is severalfold higher than in streams draining upland watersheds:

The estimated carbon accumulation falls near the lower end of the range for the estimate of carbon release from drainage of Histosols and Gleysols,

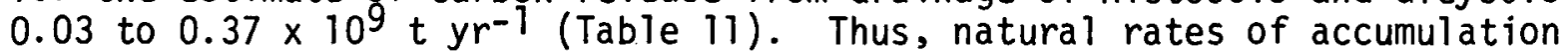
could be offsetting the release of carbon from disturbance of organic soils and maintaining a small sink, although this appears unlikely. Abandonment of drained lands would also accumulate carbon, but its significance is unknown. In developed countries of Europe and North America, some organic deposits drained in the early 20th century may soon be abandoned and then revert to organic matter accumulation, but new drainage schemes are also underway. Peat accretion in the tropics and the far North may be more significant than in the settled regions, if Neishstadt's paludification projections hold for the circumboreal forests and the tundra, and if rates of accumulation in the tropics exceed those in the temperate zone. Much more data on peat formation is needed, however, before sequestering of carbon in these organic soils can be reliably estimated. The principal weakness in our understanding of wetland carbon dynamics is in the area of decomposition and organic matter transformations within the sediments (Gallagher 1978). There are many data on primary production from a wide variety of wetland types, but carbon degradation rates have not been classified for different wetland types and geographic areas.

\section{MANAGEMENT OF PEATLANDS*}

Wetlands, including peatlands and other ecosystems characterized by organic soils, have become recognized for many values, such as absorption of waste nutrients and controlling water supplies (Good et al. 1978, Aandahl et al. 1974), largely derived from the organic nature of their sediments and their high rates of productivity. Little reference has been made to the potential for wetlands to serve as long-term repositories for fixed carbon, although undisturbed wetlands already carry out this function. Management of wetlands centers on the more recognized values, but, if successful, also assures the functioning of wetlands as carbon sinks. The following discussion describes the major components and challenges in the management of wetlands, as they affect their function as carbon sinks.

Assessing future options for peatlands use depends on first procuring data on classification, mapping and land use. With such a data base, supplemented or updated with remote sensing data, options for decisionmakers can then be outlined. These options must be sensitive to the social, economic and political realities of the countries and regions concerned, but an international overview can encourage governments and the private sector to

*Based on an analysis and presentation by R. S. Dorney. 
Table 11. Estimates of carbon release between organic soils and the atmosphere presented in the TIE workshop. Both carbon release $(+)$ and carbon uptake $(-)$ are shown along with assumptions used in each calculation. The uncertainties for the assumptions and estimates are not given. They may range up to an order of magnitude.

\section{A. Estimates of Carbon Release from Histoso]s $\left(10^{9} \mathrm{t}\left(\mathrm{yr}^{-1}\right)\right.$}

1. (t) $0.05-0.35$ (maximum)

2. (t) $0.02-0.07$

3. (t) 0.1

Range $=(+) \quad 0.02-0.35$

\section{- Assumptions}

\begin{tabular}{lllll}
\hline Carbon & & & Soil Subsi- & Carbon \\
Exchange & Area & Buik & dence from & Content \\
per Area & Drained & Density & Oxidation & of Soil \\
$\left(t \mathrm{ha}^{-1} \mathrm{yr}^{-1}\right)$ & $\left(10^{6} \mathrm{ha}\right)$ & $(\mathrm{g} \mathrm{cm})$ & $(\mathrm{cm})$ & $(\%)$ \\
\hline
\end{tabular}

5-35

3

0.15

1-3

$50 \%$

2

0.2

5 $50 \%$

B. Estimates of Carbon Release

from Gleysols

$\left(10^{9} \mathrm{t}\left(y r^{-1}\right)\right.$

1. (+) $0.015+5$

2. $(+) 0.01+10 \quad 1$

Range $=(+) \quad 0.01-0.015$

C. Estimate of

Carbon Seques-

tering in Peat

$\left(10^{9} \mathrm{t}\left(\mathrm{yr}^{-1}\right)\right.$

1. (-) $0.045 \quad(-) 0.1 \quad 450$

D. Estimate of

Net Carbon

Exchange

$(A+B-C) 10^{9}$ t $C y^{-1}$

(t) 0.320 to $(-) 0.015$ 
favor some uses over others, and through research and international funding efforts, develop more rational approaches on a long-term basis.

With this strategy, the following options can be suggested:

\section{Creation of Peatlands}

With new pressures to improve surface water quality in the United States and Canada (as exemplified by work of the International Joint Commission), and in Western Euorpe, hydrologically active or sensitive areas will probably be taken out of active crop production to be reforested or allowed to develop natural graminoid plant cover. For example, estimates of the amount of agricultural land surface in southern Ontario which will be committed could be as high as $7 \%$ to $10 \%$ of the urban surface. Similar areas might be so committed in central and eastern United States as well as in prairie wheatlands in the United States and Canada. At present, the International Joint Commission is proposing such radical land use changes in the Great Lakes basins.

Some of these lands presently in crop production were at one time organic soils (Gleysols or Histosols). Where a conversion in wetland use is made, a gradual return to natural plant cover and its associated geochemical processes would lead to organic carbon accumulation. If alternative economic uses of these wetlands, such as for forestry, fisheries, wildlife or recreation, can be developed, removal of these lands from agriculture will be accelerated. Legislation to protect wetlands, to regulate land use on the floodplain, and to designate natural areas for protection can also add impetus to this potentially substantial wetland creation process.

\section{Functional Designation for Wetlands Management}

Functional designation of wetlands identifies natural biophysical processes which benefit man and creates the impetus for maintaining wetlands in a natural state, thereby preserving their carbon storage capacity. For example, some wetlands areas reduce peak water flow, retard snow melting or act as recharge areas, depending on their location in the drainage area, their size and basin ecology. Other wetlands act as nutrient sinks, binding heavy metals and other chemicals in the organic soils and/or the vegetation. Copper, for example, is tightly bound in organic soils. When used for cleansing of waste waters, peatlands can improve water quality. Many wetlands are best preserved for fish and game production and for outdoor education and recreation. If ecosystem evaluation and land-use mapping procedures designate these wetlands functions, a case for retention in a natural state can often be made in design of urban areas, rights-of-way designation, and conversion by drainage or flooding.

\section{Use of Wetlands for Agriculture and Energy Supply}

Present uses of peatlands for agricultural production result in large carbon releases. However, growing grasses for animal forage or reclaimed 
peatland, a policy adopted in Poland, can reduce or retard subsidence and carbon loss. New or existing food crops, such as wild rice or cranberries, can also conserve the peat soil itself. Thus, carbon storage is not precluded by all forms of agricultural development. If new experimental biomass crops such as cattails, Phragmites, willow, hybrid poplars, and alder are grown on organic soils, conservation of the soil resource may also result.

Synthetic gas production is a new use presently under study by the Institute of Gas Technology in the United States, while in Western Europe and Russia, direct burning for energy is widely practiced. Both these uses irreversibly deplete the peat resource, but flooding can lead to new peat accumulation.

Forestry uses of wetlands (sawtimber, fuel wood, fence posts, mine timbers, Christmas trees, cedar boughs for floral decorations) can be significant local resources managed by small operators or farmers or part of larger commercial logging enterprises. Generally, resource extraction is carried out on a sustained yield basis using either natural regeneration or reforestation to sustain production. Some wetlands exhibit forest regeneration problems, converting more or less permanently to non-commercial trees, shrubs, graminoid plant communities (e.g., cattails) or mosses. In mid-latitudes (e.g., $44^{\circ} \mathrm{N}$ ), breakdown of the top 30 to $60 \mathrm{~cm}$ of peat can occur following logging, due to opening of the stands, introduction of more alkaline water (e.g., agricultural liming next to a bog), highway construction across a bog on calcareous till, or blocked drainage from logging roads. Forestry activities, however, generally do not damage the total peat resource and are compatible with long-term maintenance of carbon storage capacity, in addition to providing a renewable energy source.

\title{
Preservation as an Option
}

Some peatlands should be preserved intact as natural reserves or as ecological research areas. Designation should be based on the present state of naturalness and freedom from surrounding effects or impacts, size, and performance of valued ecological and public service function. Preservation ensures the continued function of wetlands as carbon sinks, and preserves options for future management.

\section{DATA UNCERTAINTIES AND RESEARCH NEEDS.}

\author{
Uncertainties in Available Data
}

Review of available data on the organic soils of the world suggests that human intervention may have converted these natural carbon sinks into carbon sources. Data uncertainties are substantial, however, and this conclusion could be wrong. Organic soils may now be in balance with respect to carbon exchange, or they may still be operating as a sink; though at a lower level than during presettlement times. Workshop participants identified the principal deficiencies in existing data that must be corrected in order to resolve the issue of the significance of organic soils to the world 
carbon budget.

Estimates of the Global Extent of Gleysols and Histosols.

- Uncertainty connected with present estimates of world deposits of organic soils (Gleysols and Histosols) may be as $10 \mathrm{w}$ as $20 \%$, if figures derived from FAO summaries are reliable. Considering uncertainties associated with data for the USSR, China, and certain tropical deposits, the precision is likely to be $\pm 50 \%$ of the estimate given by Bohn (1976), which is $4.3 \times 10^{8}$ ha for the world. For certain little-known areas, there are no accurate estimates of the extent of organic soils deposits, and present figures, though offered as the best available, are only assumptions.

Rates of Oxidation of So 11 Carbon as a Result of Human Intervention

- Current estimates of carbon oxidation rates are based on measured values for relatively few sites, such as the Sacramento-San Joaquin Delta and southern Florida. - Data are insufficient to determine whether figures for those sites are typical, and the extent of uncertainty for estimates of regional or continental deposits may be as high as $50 \%$ to $100 \%$.

For many parts of the world, but particularly for tropical eastern Asia, China, and the USSR, little information exists on the extent of drainage and expected oxidation of organic deposits in the recent past, the present or the near future. As a result, the present level of precision can be no less than $100 \%$ for estimates of changes in world pools of organic soils.

Importance of Paludification in Northern Peatlands

- The apparent rapid expansion of peatlands in western Siberia and the lack of comparable information for Canada and Alaska leave an insufficient data base for appraising the importance of paludification in the net withdrawal of carbon from the atmosphere. Verification of current rates of expansion of peatlands is needed for all deposits, particularly those of the boreal and sub-boreal zones. Information is lacking about the long-term lateral spread of peatlands as well as the rate of carbon absorption during this process.

Extent of Tropical Peatlands

- Recent estimates of the extent of organic soil deposits in tropical countries have been widely cited (e.g., Moore and Bellamy 1975), but they are underestimates. New assessments, presented in this workshop, suggest that the peatlands of southeast Asia, Indonesia, and North and South America are larger than previous estimates allowed. However, the rate of drainage and development of these peatlands is completely unknown. Although the importance 
of soil temperature in governing rates of oxidation of soil carbon is recognized, its significance in relation to the tropics must be investigated.

\section{Carbon Release from Past Agricultural Development of Wetland Soils}

- Carbon release resulting from the opening of moist prairie and marsh soils in the temperate zone during the 19th and eariy 20th centuries has been variously estimated. Even if the release of $110 \times 10^{9}$ t $C$ suggested by Wilson (1978) is only approximately correct, carbon loss during this period may be significant in - relation to the atmospheric $\mathrm{CO}_{2}$ concentration. There has been no summarization of available data on the consequences of these historical events. Similarly, though extensive drained areas have been abandoned since the period of major interventions into organic soils, their significance in creating a carbon sink has not been estimated.

\section{Effects of Fossil Fuel. Combustion Products on Wetland Processes}

- Little is known about the influence of fossil fuel. combustion by-products, such as nitrogen and sulfur, on wetland processes and natural rates of growth or degradation of peatlands. Destructive effects of acid rain and other pollutants on wetland processes are also unknown, but they may be regionaliy significant.

Although increased atmospheric carbon dioxide could stimulate the photosynthetic rate of wetland plants, it may not have a significant effect on wetlands, because photosynthetic rate is not the principal limiting factor regulating wetland growth. However, increasing $\mathrm{CO}_{2}$ may increase global temperatures, which could have a significant effect on the growth rates of peatlands. A warming climate in the higher latitudes could have an important impact on rate of accretion of peatlands, paludification, and release of carbon due to withdrawal of permafrost from tundra bogs. At present, data are insufficient for even an approximate estimate of the dynamics of the processes under the influence of changing climate. The response of wetlands to recent changes in climate is not well known. Radioisotope dating, which provides averages over some millenia, does not give any precise estimates for the period since the 19th century.

Changing Interpretation of Resource Values and the Wetland Carbon Pool

- Until now, development of organic soils for fuel and other products has probably not occurred to an extent that is significant in terms of global carbon exchange, but energy shortages are stimulating an increased interest in utilization of peat for fuel. There is also continued drainage of peatlands for afforestation. The cumulative effects of human interventions are not sufficiently known to permit an estimate of the impact of present and future human 
activities on the function of peatlands as carbon reservoirs.

Research Recommendations

Evidence established at the workshop shows that human activity has converted organic soils from a net carbon sink into a carbon source for at least part of the time since major interventions into these soils began. Data suggest that organic soils may now be releasing an amount of carbon within the range of $1.3 \%$ to $16.1 \%$ of the net increment of carbon added annually to the atmosphere. In the late 19th and early 20th centuries, the amount of carbon release from organic soils may have been even greater.

There is, however, a need for better information about the significance of organic soils today. Because estimates for net carbon exchange are too uncertain to permit definitive conclusions, workshop participants recommended research initiatives to resolve data uncertainties over the next several years, by meeting the following goals:

1. improvement of estimates of the global extent of organic soils

2. identification of areas subject to drainage

3. estimation of peat accretion rates in northern boglands

4. determination of the extent of peatlands and other organic soil deposits in presettlement areas of North America and Europe

5. evaluation of the effects of pollutants upon production, decomposition, and peat accretion in wetlands

6. evaluation of the behavior of wetlands under the influence of changing climate

7. assessment of the significance of energy resource development for peatland carbon exchange

8. establishment or designation of an organization to coordinate field research and synthes is activities by researchers in many countries.

Improving Estimates of the Global. Extent of Organic Soils

- In order to reduce uncertainties in critical areas and to test the validity of existing mapping and ecosystem-based estimates of pool sizes, critical areas for which further data are most needed, principally in the tropics and the far. North, should be identified.

- A well-defined field measurements program; coupled with remote sensing and vegetation analys is, should be initiated at carefully chosen sites. The Florida Everglades, Minnesota peatlands, or other well-studied sites should be used for ground truth and methods calibration. Soil depth and bulk density should be determined at all measurement sites.

Identifying Areas Subject to Drainage

- Sites that are undergoing drainage or will be subject to drainage 
in the near future should be located. Data may be obtained from agencies such as the United Nations, International Council of Scientific Unions, or International Peat Society, from foreign scientists, and from agriculture and forestry agencies in countries with major organic soils pools.

- In areas where major interventions are likely, soil samples from different depths should be analyzed for carbon content and bulk density, and permanent benchmarks should be established so that subsidence rates can be monitored.

- Since a coordinated, multi-national effort will be required to monitor drainage of organic soils, foreign and U.S. scientists and international agency officials should meet to compile information on peatland development programs and to plan a program of field measurements.

- Remote sensing should be explored as a means of estimating areal changes that result from the spread of agriculture or urbanization of wetlands. Use of outgoing thermal radiation (nocturnal cooling patterns) to distinguish drained from undrained Histosols has yielded promising results. Microwave sensing, in conjunction with remote sensed surface temperature analysis, may improve resolution and should be further tested.

Estimating Peat Accretion Rates in Northern Boglands

- In North America: Investigation should be started in Canada and Alasks to corroborate reports of rapid paludification in Siberia. A study should be made of release of peat from permafrost in response to global temperature amelioration, to determine whether the process is an important source of carbon. Parallel measurements of peat accretion and peat oxidation should be made at representative sites.

- In the Soviet Union: Because little is known about extensive peat beds in Siberia, Soviet and Scandinavian ecologists and peat scientists should be sought to cooperate in the effort to identify sites for study and to ga in data about peat accretion in their countries.

- In the temperate zone: To improve carbon exchange estimates for the more settled parts of the temperate zone, permanent benchmarks should be established, and low-intensity, long-term monitoring programs for such key variables as bulk density and soil carbon and nitrogen content should be initiated. Data on oxidation and subsidence rates are available for a few sites, such as Holland Marsh in Ontario and the Florida Everglades, but a wider range of estimates is needed to determine whether available data are representative. With bulk density and subsidence rate data, peatland oxidation rates can be estimated, based on the established 
relationship between subsidence rate and carbon loss.

Determining the Extent of Peatiands and Other Organic Soil Deposits in Presettlement Areas of North America and Europe

- A historical assessment should be made as a partial check on the results of carbon isotope work, which suggests that large quantities of carbon were released to the atmosphere by the opening during the past century of mid-continental rich grassland soils. With presettlement and bulk density data from current desposits., an estimate could be made of total carbon losses from draining, ditching; and vegetation clearing. The new historical data would be a valuable source of information to ascertain the magnitude of the impact of a single sustained human activity on a global elemental budget.

Evaluating the Effects of Pollutants upon Production, Decomposition, and Peat Accretion in Wet lands

- Research efforts should be made to improve understanding of the limiting factors that control production, decomposition, and peat accretion in wetlands. The influence of sulfur, nitrogen, heavy metals, and other elements may have considerable bearing on the source-sink relationships of organic soil deposits.

Evaluating the Behavior of Wetlands under the Influence of Changing Climate

- Since little is known about what might happen to wetlands carbon dynamics if average temperatures rise as a result of carbon dioxide enrichment, long-term behavior of peatlands in response to natural climatic change should be summarized and interpreted. The best approach may be to compile available data and then do mathematical modeling. If the basis for modeling is not strong enough, however, more empirical data should be gathered before model building and model validation are begun.

Assessing the Significance of Energy Resource Development for Peatland Carbon Exchange

- A study should be made of the implications for the world carbon cycle of the large-scale utilization of peat that may result from the current search for reliable energy resources. Local ecological effects, such as change in the water table, may be even more significant than carbon cycle effects, if a large amount of peat is harvested for fuel. Since massive peat deposits occur

. in areas not convenient to centrál power generation, increased peat utilization is likely, particularly in the USSR, Scandinavia, Ireland, and North America. The study should examine whether harvesting permanently alters the capacity of a site to function as a carbon sink or source of other benefits. The study will probably require additional field data to further understanding of effects 
of large-scale peat removal from specific ecosystems.

Establishing an Organization to Coordinate Field Research and Synthesis Activities by Researchers in Many Countries

- Because many of the recomended research initiatives require coordination of geographically dispersed field research and synthesis activities, an organization should be established or designated to maintain liaison with foreign scientists and agencies, to integrate research, modeling, and compilation activities, and to assure overall program coordination.

\section{WORKSHOP CONCLUSIONS}

Despite major gaps in available data on the world's organic soil deposits, evidence suggests that carbon fluxes may be large enough to be significant in the world carbon budget. Both carbon sequestering and liberation of organic carbon are occurring simultaneously in different locations at different rates. Although wetlands are natural sinks for atmospheric carbon, carbon release from human disturbance of wetlands is the dominant process of consequence. The following are the major findings of the workshop:

- The present annual carbon release has been estimated to vary from 0.03 to $0.37 \times 10^{9}$ t from world Histosols and Gleysols. The upper limit is based on the assumption that maximum utilization of Histosols occurs. While this range is about $1.3 \%$ to $16 \%$ of annual rise in atmospheric carbon, probably not all the released carbon remains airborne. If half of the released carbon remains in the atmosphere, organic soils contribute $0.6 \%$ to $8.0 \%$ of the annual rise in atmospheric carbon dioxide. Uncertainties imply that an even larger contribution is possible.

- Present releases of carbon from the Everglades Agricultural Area and the Sacramento-San Joaquin Valley in California together -about $0.17 \times 10^{9}$ t per year -- suggest that the lower limit of the world estimate is too low, particularly if major drainage of organic soils is occurring in the tropics. Knowledge of the areal extent of tropical deposits, for which estimates vary widely, and of present and planned drainage schemes must be increased before the carbon budget implications of soil reclamation can be analyzed.

- Clearing and draining of organic soils in the temperate zone during the late 19th and early 20 th centuries may have released more carbon annually at that time than in recent decades. Although estimates of carbon release in excess of $100 \times 10^{9}$ t have been suggested, the actual value may be a smaller but still significant quantity. Data are too sparse to resolve this question but could be forthcoming from historical analysis of the pattern of organic soil 
drainage in the developed areas of North America and Europe.

- The present annual rate of carbon sequestering in organic soils is estimated at $0.045 \times 10^{9}$ t per year. Since this estimate is near the lower limit of the estimated range for carbon release, the net exchange of carbon from organic soils could balance out to zero, al though wetlands are more likely to be net carbon sources. The estimate of carbon sequestering is based on only a few studies and should be improved.

- Better estimates of atmospheric exchange of world organic soils can be made if existing data are collated, especially in collaboration with foreign scientists. Data acquisition will be needed for principal carbon pools in the tropics, USSR, China, and, to a lesser extent, North America.

- Identifying major drainage programs is a top priority that must precede careful selection of sites at which benchmark soil measurements can be made periodically. A relatively small number of core measurements in critical areas is sufficient, if they are coupled with greater awareness of wetland development plans. Results from these measurements would significantly improve our understanding of wetland carbon exchange within two to four years after program initiation. 


\section{LITERATURE CITED}

Aandahl, A. R., S. W. Buol, D. E. Hill, H. H. Bailey (eds.), 1974. Histosols: Their Characteristics, Classification and Use. Number 6 in the SSSA Special Publication Series. Soil Science Society of America, Inc. Publisher. Madison, Wisconsin.

Adams, J. A. S., M. S. M. Mantovani and L. L. Lundell. 1976. Wood versus fossil fuel as a source of excess carbon bioxide in the atmosphere: a preliminary report. Science 196:54-56.

Ajtay, G. L., P. Ketner and P. Duvigneaud. 1979. Terrestrial primary production and phytomass. In: SCOPE 13. The Global Carbon Cycle. B. Bolin, E. T. Degens, S. Kemps and P. Ketner (eds.). SCOPE - International Council of Scientific Unions, J. Wiley \& Sons. Chichester.

Baes, C. F., H. E. Goeller, J. S. Olson and R. M. Rotty. 1977. Carbon dioxide and climate: the uncontrolled experiment. Amer. Sci. 65:310320 .

Bohn, H. 1976. Estimate of organic carbon in world soils. Soil Sci. Soc. Am. Proc. 40:468-470.

Bohn, H. 1978. On organic soil carbon and $\mathrm{CO}_{2}$. Tellus 30:472-475.

Bolin, B. 1977. Changes of land biota and their importance for the carbon cycle. Science 196:613-617.

Chamie, J. P. M. and C. J. Richardson. 1978. Decomposition in northern wetlands. In: Good, R. E., D. F. Whigham and R. L. Simpson (eds.). Freshwater Wetlands. Ecological Processes and Management Potential. Academic Press. New York. 378 pp.

Chan, Y. H., J. S. 01 son and W. L. Emanuel. 1979. Simulation of Land-Use Patterns Affecting the Global Carbon Cycle. Env. Sci. Div. Pub. No. 1273. Oak Ridge National Laboratory, Oak Ridge, Tennessee.

Freyer, H. D. 1978. Preliminary evaluation of past $\mathrm{CO}_{2}$ increase as derived from ${ }^{13} \mathrm{C}$ measurements and tree rings. Pp. 69-78. In: Carbon Dioxide, Climate and Society. J. Williams (ed.). Pergamon Press, 0xford. $332 \mathrm{pp}$.

Gallagher, J. L. 1978. Decomposition processes: summary and recommendations. Pp. 145-151. In: Freshwater Wetlands. Ecological Processes and Management Potential. R. E. Good, D. F. Whigham and R. L. Simpson (eds.). Academic Press. New York.

Giddens, J. 1957. Rate of loss of carbon from Georgia soils. Soil Sci. Soc. Amer. Proc. 22:513-515. 
Good, R. E., D. V. Whigham and R. L. Simpson (eds.). 1978. Freshwater Wetlands. Ecological Processes and Management Potential. Academic Press. New York. $378 \mathrm{pp}$.

Hampicke, U. 1979. Net transfer of carbon between the biota and the atmosphere, induced by man. In: SCOPE 13. The Global Carbon Cycle. B. Bol in, E. T. Degens, S. Kempe and P. Ketner (eds.). SCOPE - International Council of Scientific Unions. John Wiley \& Sons. Chichester.

Jenny, H. 1941. Factors of Soil Formation. A System of Quantitative Pedology. McGraw Hill. New York. 281 pp.

Keeling, D. C., R. B. Bacastow, A. E. Bainbridge, C. A. Ekdahl, P. R. Guenther, L. S. Waterman and J. F. S. Chin. 1976. Atmospheric carbon dioxide variations at Mauna Loa Observatory, Hawaii. Tellus 28:538-551.

Kononova, M. M. 1966. Soil Organic Matter: Its Nature, Its Role in Soil Formation and in Soil Fertility. Oxford: Pergamon. $554 \mathrm{pp}$. 2nd Ed.

Loomis, R. 1977. $\mathrm{CO}_{2}$ and the Biosphere. Adapted from a presentation to the ERDA Workshop on "Environmental Effects of Carbon Dioxide from Fossil Fuels Combusion". March 7-11, 1977. Miami Beach, Florida.

McDowe11, L. L., J. C. Stephens and E. H. Stewart. 1969. Radiocarbon chronology of the Florida Everglades Peat. Soil Sci. Soc. Amer. Proc. 33:743745 .

Moore, P. D. and D. J. Bellamy. 1975. Peatlands. Elek Science. London Pp. 1-221.

MuTholland, P. J. and E. J. Kuenzler. 1979. Organic carbon export from pland and forested wetland watersheds. Limn. Ocean. 24:960-965.

Neishtadt, M. I. 1977. The world's largest peat basin, its commercial potentialities and protection. International Peat Society Bulletin 8:37-43.

Paul, E. A. 1976. Nitrogen cycling in terrestrial ecosystems. In: Environmental Biochemistry. Volume I. J. 0. Nriagu (ed.). Ann Arbor Science Publishers, Inc." Ann Arbor.

Reader, R. J. and J. M. Stewart. 1972. The relationship between net primary production and accumulation for a peatland in southeastern Manitoba. Ecology 53:1024-1037.

Revelle, R. and M. W. Munk. 1977. The carbon dioxide cycle and the biosphere'. Pp. 243-281. In: Energy and Climate. Studies in Geophysics. Panel on Energy and Climate. National Research Council, National Academy of Sciences, Washington, D.C. 
Richardson, C. J. 1979. . Primary productivity values in freshwater wetlands Water Resources. In press:

Rigg, G. B. and H. R. Gould, 1957. Age of Glacier Peak eruption and chronology of post-glacial peat. deposits in Washington and surrounding areas. Amer, J. Sci. 155:341-363.

Rubilin, Y. V. and V. A. Dolotov. 1967. Effect of cultivation on the amounts and composition of humus in gray forest soils. Sov. Soil Sci. 1967: 733-738.

Schlesinger, W. 1977. Carbon balance in terrestrial detritus. Ann. Rev. Ecol. Syst. 8:51-81.

Schlesinger, $W:$ 1979. The world carbon pool in soil organic matter: a source of atmospheric $\mathrm{CO}_{2}$ ? In: G. M. Woodwell (ed.): The Role of Terrestrial Vegetation in the Global Carbon Cycle: Methods for Appraising Changes. John Wiley and Sons. In press.

Shih, S. F., J. W. Mishoe, J. W. Jones, and D. L. Myhre. 1979. Subsidence related to land use in Everglands Agricultural Area. Trans. of the ASAE 22:561-568.

Soil Survey Staff. 1974. Soil taxonomy: A basic system of soil classification for making and interpreting soil surveys. USDA Agricultural Handbook No. 436. U. S. Government Printing Office, Washington, D.C.

Stephens, J. C. 1951. Subsidence of organic soils in the Florida Everglades. Soil Sci. Soc. Amer. Proc. 20:78-80.

Stephens, J. C. 1974. Subsidence of organic soils in the Florida Everglades a review and update. From MEMOIR 2: Environments of South Florida:

Present and Past. Miami Geological Society, Miami, Florida.

Stephens, J. C. and Johnson L. 1951. Subsidence of peat soils in the Everglades Region of Florida. Contribution from the Division of Drainage and Water Control. USDA Soil Conservation Service.

Stephens, J. C. and W. H. Speir. 1969. Subsidence of organic soils in the U.S.A. Assoc. Internat. D'Hydrol. Scient. Extrait de la Publication No. 89. Actes du Colloque de Tokyo.

Stephens, J. C. and E. H. Stewart. 1976. Effect of climate on organic soil subsidence. Pp. 647-655. In: Land Subsidence Symposium. IAHS - AISH Pub. No. 121. Proceedings of the Second International Symposium on Land's Subsidence held at Anaheim, California.

Stuiver, M. 1978. Atmospheric carbon dioxide and carbon reservoir changes. Science 199:253-258. 
Wagener, K. 1978. Total anthropogenic $\mathrm{CO}_{2}$ production during the period 1860-1975 from ${ }^{13} \mathrm{C}$ measurements. Unpublished manuscript.

Weir, W. W. 1950. Subsidence of peat lands of the Sacramento-San Joaquin Delta, California. Hilgardia 20(3):37-56:

Wilson, A. T. 1978. Pioneer agriculture explosion and $\mathrm{CO}_{2}$ levels in the atmosphere. Nature 273:40-41.

Woodwell, G. M., P. H. Rich and C. A. S. Hall. 1973. Carbon in estuaries. Pp 221-240. In: Carbon and the Biosphere. G. M. Woodwell and E. V. Pecan (eds.). Technical Information Center, Office of Information Services. United States Atomic Energy Commission.

Woodwell. G. M., R. H. Whittaker, W. A. Reiners, G. E. Likens, C. C. Delwiche, and D. B. Botkin. 1978. The biota and the world carbon budget. Science 199:141-146. 


\section{WORKSHOP PARTICIPANTS}

\section{$\mathrm{CO}_{2}$ Workshop on Organic Soils.}

May 7 and 8, 1979

Dr. Leon H. Allen, Jr.

Soil and Water Unit University of Florida Gainesville, FL 32611

Dr. C. C. Delwiche Department of Soils University of California-Davis Davis, CA 95616

Dr. C. J. Richardson School of Forestry and Environmental Studies Duke University Durham, NC 27706

Dr. Robert S. Dorney

Vice President

Research and Development

Ecoplans, Ltd.

Waterloo, Ontario

Canada N2L 4E2

Dr. John Duxbury

Agronomy Department

Cornell University

Ithaca, NY 14850

Dr. Hinrich L. Bohn

Department of Soils, Water and Engineering

University of Arizona

Tucson, AZ 85721
Dr. S. P. Mathur

Chemistry and Biology Research Institute

Agricul ture Canada

Ottawa, Ontario

Canada KIA OC6

Dr. D. E. Willard

School of Public and Environmental Affairs

Indiana University

Bloomington, IN 47405

Dr. Rouse Farnham

Department of Soil Science

University of Minnesota

St. Paul, MN 55108

Dr. Donald Franzmeier

Department of Agronomy

Purdue University

Lafayette, IN 47907

Dr. Orie L. Loucks

Science Director

The Institute of Ecology

Holcomb Research B1dg., Butler University

Indianapolis, IN 46208

Dr. Thomas V. Armentano

Research Scientist

The Institute of Ecology

Hol comb Research B1dg., Butler University

Indianapol is, IN 46208 